\title{
Low Relative Humidity at Harvest and Before Storage at High Humidity Influence the Severity of Postharvest Peel Pitting in Citrus
}

\author{
Fernando Alferez \\ University of Florida, IFAS, Citrus Research and Education Center, 700 Experiment Station Road, \\ Lake Alfred, FL 33850-2299 \\ Lorenzo Zacarias \\ Instituto de Agroquimica y Tecnologia de Alimentos, CSIC, Apartado de Correos 73, Burjassot, Valencia \\ 46100 Spain
}

\author{
Jacqueline K. Burns ${ }^{1}$ \\ University of Florida, IFAS, Citrus Research and Education Center, 700 Experiment Station Road, \\ Lake Alfred, FL 33850-2299
}

\begin{abstract}
Additional index words. 'Fallglo' tangerines, 'Marsh' grapefruit, water relations, commercial waxes, peel disorders, climatic factors

Abstract. Several citrus cultivars including 'Marsh' grapefruit (Citrus paradisi Macf.) and 'Fallglo' tangerine [Bower citrus hybrid $(C$. reticulata Blanco $\times C$. reticulata $\times C$. paradisi $) \times$ Temple tangor $(C$. reticulata $\times C$. sinensis $\mathrm{L}$. Osbeck $)]$ are prone to develop postharvest peel pitting at nonchilling temperatures. This disorder is characterized by depressions in flavedo that ultimately affect oil glands. Although the fundamental cause for this disorder has not been well defined, increasing evidence indicates that alteration in peel water status during postharvest handling of fruit plays a major role. 'Fallglo' tangerines developed postharvest peel pitting when transferred from low $(30 \%)$ to high $(90 \%)$ relative humidity (RH) storage. To determine the number of hours of dehydration prior to storage at high RH sufficient to induce peel pitting in 'Marsh' grapefruit and 'Fallglo' tangerines, fruit were exposed to low RH conditions for increasing periods of time and then washed, coated with commercial shellac-based wax, and stored at high RH. Only 2 hours of low RH storage were sufficient to induce peel pitting in 'Fallglo' and 'Marsh' after transfer to high RH. The severity of pitting in 'Fallglo' tangerines was greater than in 'Marsh' grapefruit. Weight loss of fruit at the end of low RH storage and peel pitting after 3 weeks of storage at high RH were significantly correlated. RH conditions in the field at the time of harvest affected susceptibility to peel pitting in both cultivars. Peel pitting was more severe when fruit were harvested at low field RH than high field RH when followed by treatments that induce peel pitting. The data suggest that harvesting susceptible cultivars at high $\mathrm{RH}$, and minimizing exposure to low $\mathrm{RH}$ after harvest, could reduce the commercial impact of postharvest peel pitting.
\end{abstract}

Postharvest peel pitting at nonchilling temperatures is a storage disorder described in a number of citrus cultivars, including 'Navelina' sweet orange (C. sinensis) (Casas and Garcia-Bataller, 1986; Lafuente and Sala, 2002), 'Navelate' sweet orange (Agusti et al., 2001), 'Marsh' grapefruit (Petracek et al., 1995), and 'Fallglo' tangerine (Petracek et al., 1998). Peel pitting diminishes the quality of fruit for fresh market and can cause important economic losses. Peel pitting is characterized by collapse of fruit subepidermal cells. The disorder begins with depressions on the peel and later affects cells surrounding oil glands and adjacent areas of the flavedo (Agusti et al., 2001; Alferez et al., 2003; Petracek et al., 1995). After a few days, affected cells become more compressed. As cellular and oil gland contents are released into the intercellular spaces, depressions turn bronze in color, probably due to subsequent enzymatic oxidation (Agusti et al., 2001; Alferez and Burns, 2004; Lafuente and Sala, 2002). Over time, large areas of the fruit surface can be affected. Although the fundamental cause for this disorder has been not well defined, increasing evidence

Received for publication 8 July 2004. Accepted for publication 19 Aug. 2004. This research was supported by the Florida Agricultural Experiment Station and approved for publication as Journal Series No. R-10333.

To whom reprint requests should be addressed. E-mail address: jkbu@crec. ifas.ufl.edu indicates that variations in RH during postharvest handling and storage change the water status in fruit and lead to peel pitting in 'Navelina' and 'Navelate' orange (Agusti et al., 2001; Alferez et al., 2003) and in 'Marsh' grapefruit (Alferez and Burns, 2004). Previous work showed a significant positive correlation between peel pitting index (PPI) and percent cumulative weight loss prior to postharvest storage at high relative humidity $(\mathrm{RH})$. However, the low correlation coefficient suggested that changes in RH during postharvest storage might not be the sole cause of the disorder (Alferez and Burns, 2004). It has been reported that several inductive factors may lead to similar disorders in citrus peel (Grierson, 1986), and as such, it has been difficult to ascribe a particular cause to a symptom. However, the widespread nature of peel pitting among cultivars and its incidence in different citrus growing regions in the world suggest that there may be common factors causing this disorder. Environmental conditions such as temperature and RH in the field have been proposed to explain the erratic incidence of peel pitting (Agusti et al., 2001; Alferez et al., 2003; Casas and Garcia-Bataller, 1986; Petracek et al., 1995).

These observations prompted us to undertake a study with two objectives. The first objective was to define a threshold time of low RH storage in which fruit can be held before storage at 
high RH without promoting peel pitting. 'Fallglo' tangerine was selected because of its increased susceptibility to develop peel pitting (Petracek et al., 1998), whereas 'Marsh' grapefruit was selected because its susceptibility to the disorder is less. The second objective was to determine if $\mathrm{RH}$ at the time of harvest influences the development of this peel disorder in 'Fallglo' tangerine and 'Marsh' grapefruit in Florida.

\section{Materials and Methods}

Plant Materials. Mature 'Fallglo' tangerines from 15-yearold trees on sour orange rootstock (Citrus aurantium L.) used in experiments were harvested at a commercial grove in Haines City, Fla., on 21 Oct., 28 Oct., and 13 Nov. 2003 at $\approx 1100$ HR. On 21 Oct., fruit were harvested by grasping the fruit and pulling away from the stem, whereas fruit were harvested on the two remaining dates by clipping the stem just above the calyx to avoid the rupture of peel oil glands (oleocellosis). Harvested fruit were uniform in size and free from peel defects. After harvest, fruit were transported to the packinghouse facilities located at the Citrus Research and Education Center (CREC) in Lake Alfred, Fla. Time between harvesting and processing of the fruit did not exceed 20 min in any 'Fallglo' experiment.

Mature 'Marsh' white grapefruit were harvested at two locations in two consecutive seasons. In season 1 , fruit were harvested from 15 -year-old trees on sour orange rootstock from a commercial grove in Vero Beach, Fla., in Mar. 2003. Fruit were transported to the packinghouse at CREC within $3 \mathrm{~h}$. During transport average $\mathrm{RH}$ was of $42 \% \pm 2 \%$ and temperature was $24 \pm 2{ }^{\circ} \mathrm{C}$. In season 2, fruit were harvested from 15-year-old trees located at CREC in Mar. 2004. Fruit were harvested on two different dates, each with disparate RH conditions in the field but similar temperatures. On 11 Mar. 2004, fruit were harvested when RH was $44 \%$ and temperature was $20^{\circ} \mathrm{C}$, whereas on 16 Mar., fruit were harvested at $89 \% \mathrm{RH}$ and $21{ }^{\circ} \mathrm{C}$. In both cases, harvesting was carried out at $0900 \mathrm{HR}$. Fruit were delivered to the packinghouse within 20 min after harvest.

Conditions OF STORAGE. ExPT. 1. To determine if low RH storage prior to washing and waxing 'Fallglo' tangerines promoted peel pitting, fruit harvested on 21 Oct. 2003 were randomly divided into eight duplicated lots of 30 fruit each. Two lots were washed and stored for $10 \mathrm{~d}$ either at $30 \% \pm 1 \% \mathrm{RH}$ and $20 \pm 1{ }^{\circ} \mathrm{C}$ [vapor pressure deficit (VPD) $1637 \mathrm{~Pa}$ ] or $90 \% \pm 1 \% \mathrm{RH}$ and $20 \pm 1{ }^{\circ} \mathrm{C}$ $(\mathrm{VPD}=233 \mathrm{~Pa})$ and were considered as controls for washed fruit. Two additional lots were washed and waxed immediately after harvest and stored at the same conditions, and these were considered as controls for the washed and waxed fruit. The remaining four duplicated lots were stored for 2 or $6 \mathrm{~d}$ at $20 \pm 1{ }^{\circ} \mathrm{C}$ and $30 \% \pm$ $1 \% \mathrm{RH}$. After 2 or $6 \mathrm{~d}$ of storage at $30 \% \mathrm{RH}$, one of the duplicated lots of 30 fruit was washed and transferred to $90 \% \mathrm{RH}$, or washed and coated with commercially available shellac-based wax (StaFresh 590 HS; FMC Food Tech, Lakeland, Fla.) on conventional commercial brushes and air-dried prior to transfer to $90 \% \mathrm{RH}$. Fruit remained in $90 \%$ RH storage for $4 \mathrm{~d}$ before evaluation for peel pitting. Table 1 outlines treatment strategies for Expts. 1, 2 , and 3 . In all experiments, $\mathrm{RH}$ was continuously monitored. A $30 \% \mathrm{RH}$ was achieved by placing an electric dehumidifier in the storage room, whereas a $90 \% \mathrm{RH}$ was the equilibrium $\mathrm{RH}$ achieved by storing plant material in the rooms.

ExPT. 2. To study the effect of cumulative hours of low RH storage on the incidence and severity of pitting, eight duplicated lots of 30 uniform 'Fallglo' tangerine fruit were used. One duplicated lot was washed and waxed on conventional commercial brushes on the packingline immediately after harvest and kept at $90 \% \pm$ $1 \% \mathrm{RH}$ for $21 \mathrm{~d}$, and was considered as the control lot (Table 1). Seven duplicated lots were stored at $20 \pm 1{ }^{\circ} \mathrm{C}$ and $30 \% \pm 1 \%$ RH. After 2, 4, 8, 16, 24, 48, or 72 h, duplicated unwashed and unwaxed lots were then washed, waxed, and transferred to $90 \%$ RH storage for $21 \mathrm{~d}$. This experiment was conducted on 28 Oct. and 13 Nov. 2003. A comparative experiment was performed with 10 duplicated lots of 'Marsh' grapefruit harvested at CREC on 24 Mar. 2004. Fruit were washed and waxed after 3 h, 6 h, 9 h, 12 h, 24 h, 48 h, 72 h, 6 d, or $10 \mathrm{~d}$ at $30 \%$ RH, and then transferred to $90 \% \mathrm{RH}$ for $21 \mathrm{~d}$. A duplicated control lot of grapefruit was established as with 'Fallglo'.

ExPT. 3. The effect of RH at the time of harvest on development and severity of peel pitting was investigated in 'Fallglo' tangerines and 'Marsh' grapefruit. For both cultivars, fruit were harvested at contrasting RH conditions but similar temperatures. In the case of 'Marsh' grapefruit, fruit were harvested on 11 Mar. $2004\left(39 \% \mathrm{RH}, 21^{\circ} \mathrm{C}, \mathrm{VPD}=1520 \mathrm{~Pa}\right)$ and $16 \mathrm{Mar} .2004(94 \%$ $\left.\mathrm{RH}, 21^{\circ} \mathrm{C}, \mathrm{VPD}=150 \mathrm{~Pa}\right)$. RH was measured over a period of $10 \mathrm{~d}$ before both harvest dates. In both cases, RH fluctuated between $25 \%$ and $94 \%$ during a night/day cycle. Fruit were divided into four duplicated lots of 30 fruit each. One duplicated lot was washed and waxed on conventional commercial brushes on the packingline and stored at $90 \% \pm 1 \% \mathrm{RH}$ for $21 \mathrm{~d}$, and was considered as the control lot (Table 1). The remaining three duplicated lots were stored for 1,3 or $6 \mathrm{~d}$ at $20 \pm 1{ }^{\circ} \mathrm{C}$ and $30 \%$ $\pm 1 \%$ RH. After $1 \mathrm{~d}, 3 \mathrm{~d}$, or $6 \mathrm{~d}$, a duplicated lot was washed and waxed and then transferred to $90 \%$ RH. In the case of 'Fallglo' tangerines, fruit were harvested on 13 Nov. 2003 (42\% RH, 26 $\left.{ }^{\circ} \mathrm{C}, \mathrm{VPD}=1950 \mathrm{~Pa}\right)$ and 28 Oct. 2003 (89\% RH, $24{ }^{\circ} \mathrm{C}, \mathrm{VPD}$ $=330 \mathrm{~Pa}$ ). RH measured over a period of $10 \mathrm{~d}$ before harvest ranged from $40 \%$ to $94 \%$ during a night/day cycle. Fruit were divided into three duplicated lots of 30 fruit each. One duplicated lot was washed and waxed on conventional commercial brushes on the packingline and kept at $90 \% \pm 1 \% \mathrm{RH}$ for $21 \mathrm{~d}$, and was considered as the control lot. The remaining two duplicated lots were stored for 1 or $3 \mathrm{~d}$ at $20 \pm 1{ }^{\circ} \mathrm{C}$ and $30 \% \pm 1 \% \mathrm{RH}$. After 1 or $3 \mathrm{~d}$, a duplicated lot was washed and waxed and then transferred to $90 \%$ RH. Peel pitting was evaluated after $21 \mathrm{~d}$ at high RH storage (Table 1).

ESTIMATION OF PEEL PITTING AND CUMUlative WEIGHT LOSS. At various times during experiments, fruit were inspected and peel pitting quantified. Peel pitting was evaluated following two procedures. The first procedure used a PPI estimate as previously described (Alferez et al., 2003). Briefly, fruit were visually rated on a scale according to the number and extent of pits, from 0 (no pits) to 3 (severe pitting) and PPI calculated according to: $\Sigma$ [peel pitting scale $(0-3) \times$ number of fruit within each class]/total number of fruit. The second procedure used the visual-rating procedure described by Petracek et al. (1998) that takes into account the number of collapsed oil glands on the surface of the peel in affected areas. In this case, severity of damage was rated using a visual scale based on the number of collapsed oil glands/fruit ( 0 $=$ no pits, $1=1$ to 3 pits, $2=4$ to 10 pits, $3=11$ to 30 pits, $4=31$ to 100 pits, $5=$ more than 100 pits). Cumulative percent weight loss was monitored during the experiments and data presented as the mean \pm SE.

Statistical analysis. Means of percentage cumulative weight loss and PPI were analyzed using the regression procedure. Analy- 
Table 1. Treatment strategy outline for Expts. 1, 2, and 3. Each lot consisted of two replicates of 30 fruit. 'Fallglo' tangerine was used in Expt. 1, whereas 'Marsh' grapefruit and 'Fallglo' tangerine were used in Expts. 2 and 3. Fruit were held at $20^{\circ} \mathrm{C}$.

\begin{tabular}{|c|c|c|c|c|c|c|}
\hline & & & $\begin{array}{l}\text { Treatment in } \\
\text { packinghouse }\end{array}$ & Time at $30 \%$ & $\begin{array}{l}30 \% \text { RH storage } \\
\text { and before } 90 \%\end{array}$ & Time at $90 \%$ \\
\hline & Treatment & Lot & before storage & $\mathrm{RH}^{\mathrm{z}}$ storage & RH storage & RH storage \\
\hline \multirow[t]{8}{*}{ Expt. 1} & Control & 1 & wash & $10 \mathrm{~d}$ & - & - \\
\hline & & 2 & wash & - & - & $10 \mathrm{~d}$ \\
\hline & & 3 & wash + wax & $10 \mathrm{~d}$ & - & - \\
\hline & & 4 & wash + wax & - & - & $10 \mathrm{~d}$ \\
\hline & Transferred fruit & 5 & - & $2 \mathrm{~d}$ & wash & $4 \mathrm{~d}$ \\
\hline & & 6 & - & $2 \mathrm{~d}$ & wash + wax & $4 \mathrm{~d}$ \\
\hline & & 7 & - & $6 \mathrm{~d}$ & wash & $4 d$ \\
\hline & & 8 & - & $6 \mathrm{~d}$ & wash + wax & $4 d$ \\
\hline \multirow[t]{14}{*}{ Expt. 2} & Control & 1 & wash + wax $(T, G)^{z}$ & - & - & $21 \mathrm{~d}$ \\
\hline & Transferred fruit & 2 & - & $2 \mathrm{~h}(\mathrm{~T})$ & wash + wax & $21 \mathrm{~d}$ \\
\hline & & & - & $3 \mathrm{~h}(\mathrm{G})$ & & \\
\hline & & 3 & - & $4 \mathrm{~h}(\mathrm{~T})$ & wash + wax & $21 \mathrm{~d}$ \\
\hline & & & - & $6 \mathrm{~h}(\mathrm{G})$ & & \\
\hline & & 4 & - & $8 \mathrm{~h}(\mathrm{~T})$ & wash + wax & $21 \mathrm{~d}$ \\
\hline & & & - & $9 \mathrm{~h}(\mathrm{G})$ & & \\
\hline & & 5 & - & $16 \mathrm{~h}(\mathrm{~T})$ & wash + wax & $21 \mathrm{~d}$ \\
\hline & & & - & $12 \mathrm{~h}(\mathrm{G})$ & & \\
\hline & & 6 & - & $24 \mathrm{~h}(\mathrm{~T}, \mathrm{G})$ & wash + wax & $21 \mathrm{~d}$ \\
\hline & & 7 & - & $48 \mathrm{~h}(\mathrm{~T}, \mathrm{G})$ & wash + wax & $21 \mathrm{~d}$ \\
\hline & & 8 & - & $72 \mathrm{~h}(\mathrm{~T}, \mathrm{G})$ & wash + wax & $21 \mathrm{~d}$ \\
\hline & & 9 & - & $6 \mathrm{~d}(\mathrm{G})$ & wash + wax & $21 \mathrm{~d}$ \\
\hline & & 10 & - & $10 \mathrm{~d}(\mathrm{G})$ & wash + wax & $21 \mathrm{~d}$ \\
\hline \multirow[t]{4}{*}{ Expt. 3} & Control & 1 & wash + wax $(T, G)$ & - & - & $21 \mathrm{~d}$ \\
\hline & Transferred Fruit & 2 & - & $1 \mathrm{~d}(\mathrm{G}, \mathrm{T})$ & wash + wax & $21 \mathrm{~d}$ \\
\hline & & 3 & - & $3 \mathrm{~d}(\mathrm{G}, \mathrm{T})$ & wash + wax & $21 \mathrm{~d}$ \\
\hline & & 4 & - & $6 \mathrm{~d}(\mathrm{G})$ & wash + wax & $21 \mathrm{~d}$ \\
\hline
\end{tabular}

${ }^{\mathrm{z}} \mathrm{G}=$ grapefruit $; \mathrm{T}=$ tangerine; $\mathrm{RH}=$ relative humidity .

sis of variance and Duncan's multiple range test were performed on means of PPI after cumulative hours of dehydration using the statistical package available in SAS (Cary, N.C.).

\section{Results}

Expt. 1. Changing Postharvest STORage RH From 30\% To 90\% PROMOTED PEel PitTing IN 'FALLgLo' tangerine. 'Fallglo' tangerine was selected for these studies because it is very susceptible to develop peel pitting, and significant economic losses occur in this variety (Petracek et al., 1998). PPI of fruit stored constantly at $30 \%$ (low) or $90 \%$ (high) $\mathrm{RH}$ remained around 0.2 , and no difference was found between washed and waxed and washed fruit (Fig. 1). PPI sharply increased when fruit were transferred from low to high $\mathrm{RH}$, and this effect was more pronounced if fruit were waxed before transfer to high RH. More prolonged storage at low RH resulted in higher PPI after transfer to high RH. The number of collapsed oil glands increased with time of storage at high $\mathrm{RH}$, and later stages were characterized by increased amount of affected flavedo tissue, including tissue between oil glands, and generalized browning (Fig. 2A-D). In cases where harvesting was done by grasping the fruit by hand, oleocellosis was also present.

Expt. 2. Cumulative hours of LOW RH StORage before HIGH RH STORAGE INCREASED THE INCIDENCE OF PEEL PITTING AND PERCENTAGE OF AFFECTED FRUIT. Previous work with 'Marsh' grapefruit demonstrated a significant correlation between duration of low RH storage before transfer of fruit to high RH storage and PPI (Alferez and Burns, 2004). This result led us to examine the time of low RH storage necessary to develop peel pitting in both 'Marsh' grapefruit and 'Fallglo' tangerine. 'Marsh' grapefruit was subjected to increasing time of low RH storage, then washed, waxed, and stored at high RH for up to $21 \mathrm{~d}$. After 1 week of storage at constant high $\mathrm{RH}$, fruit did not develop pitting 


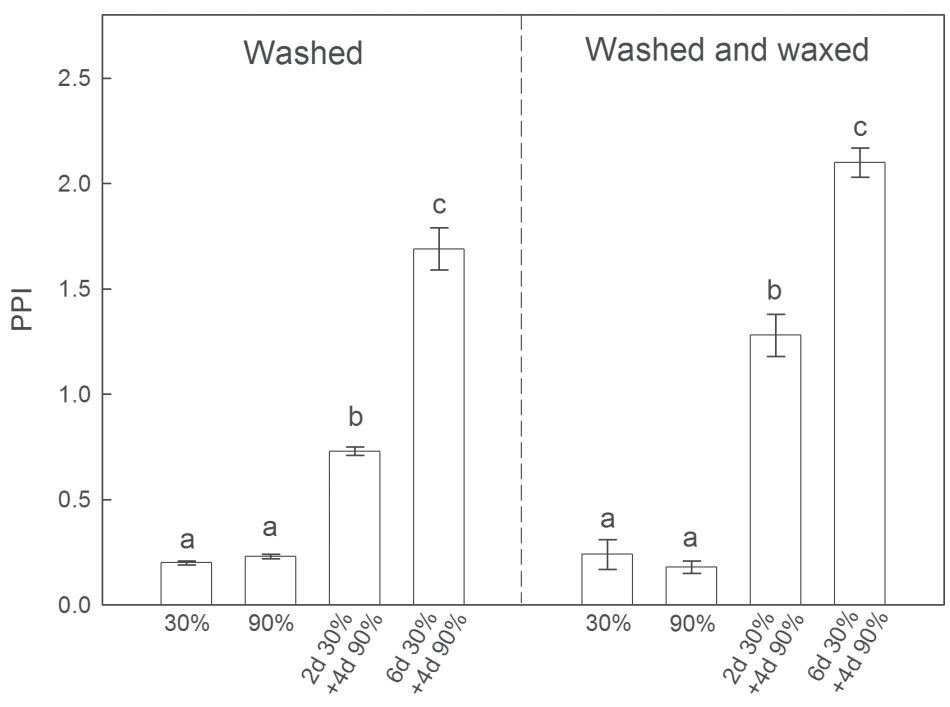

Storage conditions

Fig. 1. Peel pitting index (PPI) of 'Fallglo' tangerines stored at $20{ }^{\circ} \mathrm{C}$ and $30 \%$ or $90 \%$ relative humidity (RH) and of fruit transferred to $90 \% \mathrm{RH}$ after 2 or $6 \mathrm{~d}$ of storage at $30 \%$ RH. Fruit were washed prior to transfer to $90 \%$ RH (left panel) or washed and waxed prior to transfer to $90 \% \mathrm{RH}$ (right panel). Controls were washed (left panel) or washed and waxed (right panel) immediately after harvest and stored at $30 \%$ or $90 \% \mathrm{RH}$ for $10 \mathrm{~d}$. Data are means with SE shown ( $\mathrm{n}=30$ fruit per two lots). Means with the same letter within the same panel are not significantly different from one another $(P<0.05)$.

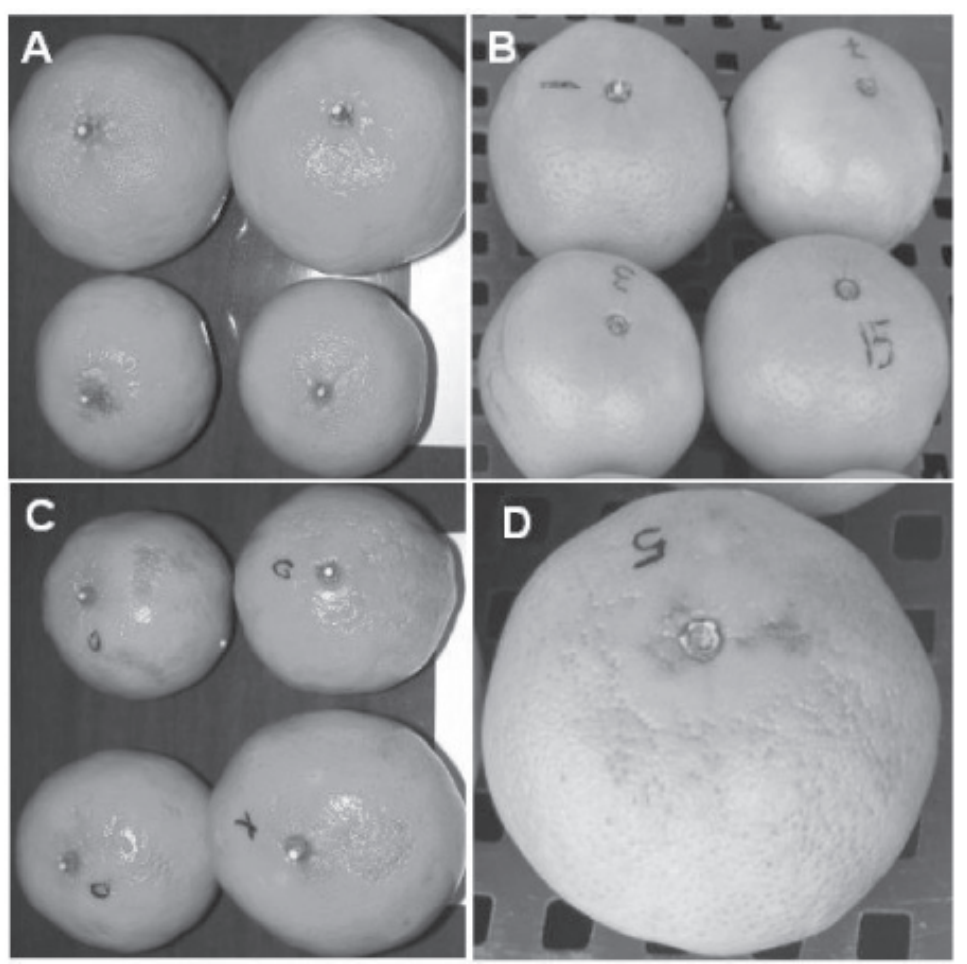

Fig. 2. Postharvest peel pitting in 'Fallglo' tangerines. Peel pitting did not develop in fruit immediately washed and waxed after harvest and stored for $21 \mathrm{~d}$ at (A) $90 \%$ relative humidity (RH) or (B) 30\% RH. (C) Peel pitting in fruit kept for $16 \mathrm{~h}$ at $30 \%$ $\mathrm{RH}$ and then washed, waxed, and stored at $90 \%$ RH for 21 d. (D) Symptoms of peel pitting in fruit kept for $16 \mathrm{~h}$ at $30 \% \mathrm{RH}$ and then washed and stored at $90 \% \mathrm{RH}$ for $21 \mathrm{~d}$. Temperature of storage was $20^{\circ} \mathrm{C}$. symptoms (Table 2). PPI of fruit held between 3 and $9 \mathrm{~h}$ at low RH prior to washing and waxing and transfer to high RH was between 0.1 and 0.24 , whereas PPI of fruit held at low $\mathrm{RH}$ between 12 and $72 \mathrm{~h}$ was $\approx 0.5$ to 0.6 . More prolonged periods of low RH storage ( 6 or $10 \mathrm{~d}$ ) before transfer to high RH increased PPI to about 0.7. After 3 weeks of high RH storage, PPI of fruit previously kept for $3 \mathrm{~h}$ at low RH was similar to that of controls (PPI $=0.1)$, but $6 \mathrm{~h}$ of low $\mathrm{RH}$ storage caused a three-fold increase in PPI. PPI in fruit kept for 6 or $10 \mathrm{~d}$ at low RH before transfer to high RH was 1.15 and 1.2 , respectively.

To study the effect of dehydration time prior to washing, waxing and transfer to high RH storage in a more susceptible cultivar, a similar experiment was carried out using 'Fallglo' tangerines. Harvested fruit were held for periods of up to 72 $\mathrm{h}$ at $30 \% \mathrm{RH}$, then fruit were washed, waxed and stored at $90 \% \mathrm{RH}$ for up to $21 \mathrm{~d}$. Only $2 \mathrm{~h}$ of low RH storage before transfer to high $\mathrm{RH}$ were enough to promote a 6 - and 10 -fold increase in PPI after 1 or 3 weeks of storage at high $\mathrm{RH}$, respectively (Table 2). In general, peel pits were more numerous in 'Fallglo' tangerines than in 'Marsh' grapefruit and final PPI observed was greater after storage at high RH.

When both cultivars were stored at low $\mathrm{RH}$ for periods up to $72 \mathrm{~h}$, a significant positive correlation was found between PPI observed $21 \mathrm{~d}$ after high RH storage and cumulative percentage weight loss at the end of the low RH storage treatment $(P<0.01$; Fig. 3A), indicating that the higher the weight loss at the end of low RH storage period, the more pitting developed after storage at high RH. Interestingly, when 'Marsh' grapefruit were stored at low RH for more prolonged periods ( 6 and $10 \mathrm{~d}$ ) before transfer to high $\mathrm{RH}$, the relationship between PPI at the end of the experiment and cumulative weight loss at the end of low RH storage was sigmoidal (Fig. 3B), suggesting that water loss becomes less of a determinant of peel pitting symptoms at these later times of low RH storage.

In attempt to compare results presented here with those previously reported, postharvest peel pitting was rated according to Petracek et al. (1998). The number of collapsed oil glands was counted and peel pitting in fruit rated from 0 to 5 in 'Fallglo' tangerines previously kept for 2,8 , and $16 \mathrm{~h}$ at $30 \% \mathrm{RH}$ prior to washing, waxing, and transfer to $90 \% \mathrm{RH}$ storage for up to $21 \mathrm{~d}$. In general, the number of collapsed oil glands and hence peel pitting severity increased with time of storage at high RH, and with increasing time of previous low RH storage (Fig. 4).

EXPT. 3. RH AT HARVEST AFFECTED SUSCEPTIBILITY TO PEEL PITTING. 'Fallglo' tangerines were harvested on three dates with disparate RH but similar temperature conditions at the time of harvest. Whereas fruit harvested at $89 \% \mathrm{RH}$ and after rain did not develop peel pitting, fruit harvested at $42 \% \mathrm{RH}$ developed severe peel pitting (PPI $=2.52$ ) after $3 \mathrm{~d}$ of low RH storage followed by 3 weeks at $90 \%$ RH (Table 3). In a similar way, 'Marsh' grapefruit were harvested on two dates with differing field $\mathrm{RH}$ conditions but similar temperatures. Fruit harvested at 94\% RH did not develop peel pitting (PPI $=0$; Table 3). In contrast, fruit harvested at $39 \% \mathrm{RH}$ and submitted to 1, 3, or $6 \mathrm{~d}$ of low RH storage prior to washing, waxing, and storage at high RH had increased PPI by the end of the experiment. 
Table 2. Peel pitting index in 'Marsh' grapefruit and 'Fallglo' tangerine stored at 90\% relative humidity (RH) and $20^{\circ} \mathrm{C}$ for 1,2 , or 3 weeks after washing and waxing. Fruit were stored at $30 \% \mathrm{RH}$ for periods of 0 to $10 \mathrm{~d}$ ('Marsh') or 0 to $72 \mathrm{~h}$ ('Marsh' and 'Fallglo') at $20{ }^{\circ} \mathrm{C}$ prior to storage at $90 \% \mathrm{RH}$.

Weeks of storage at $90 \% \mathrm{RH}$ after waxing

Time of $30 \%$

RH storage

1

2

'Marsh' grapefruit

$0 \mathrm{~h}$

$0.0 \mathrm{a}^{\mathrm{z}}$

$0.0 \mathrm{a}$

$3 \mathrm{~h}$

$6 \mathrm{~h}$

$9 \mathrm{~h}$

$12 \mathrm{~h}$

$24 \mathrm{~h}$

$48 \mathrm{~h}$

$72 \mathrm{~h}$

$6 \mathrm{~d}$

$10 \mathrm{~d}$

$0.11 \mathrm{~b}$

$0.11 \mathrm{~b}$

$0.13 \mathrm{~b}$

$0.18 \mathrm{c}$

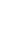

$\mathrm{h}$

$0.24 \mathrm{c}$

$0.32 \mathrm{~d}$

$0.52 \mathrm{~d}$

$0.54 \mathrm{e}$

$0.55 \mathrm{~d}$

$0.71 \mathrm{f}$

$0.56 \mathrm{~d}$

$0.75 \mathrm{fg}$

$0.58 \mathrm{~d}$

$0.79 \mathrm{~g}$

$0.75 \mathrm{e}$

$0.93 \mathrm{~h}$

'Fallglo' tangerine

$\begin{array}{llll}0 \mathrm{~h} & 0.07 \mathrm{a} & 0.12 \mathrm{a} & 0.15 \mathrm{a} \\ 2 \mathrm{~h} & 0.43 \mathrm{~b} & 0.70 \mathrm{~b} & 1.10 \mathrm{~b} \\ 4 \mathrm{~h} & 0.43 \mathrm{~b} & 0.80 \mathrm{~b} & 1.13 \mathrm{~b} \\ 8 \mathrm{~h} & 0.72 \mathrm{c} & 1.10 \mathrm{c} & 1.80 \mathrm{c} \\ 16 \mathrm{~h} & 0.77 \mathrm{c} & 1.20 \mathrm{~cd} & 2.10 \mathrm{~d} \\ 24 \mathrm{~h} & 0.76 \mathrm{c} & 1.35 \mathrm{~d} & 2.16 \mathrm{~d} \\ 48 \mathrm{~h} & 0.80 \mathrm{c} & 1.38 \mathrm{~d} & 2.23 \mathrm{~d} \\ 72 \mathrm{~h} & 0.75 . \mathrm{c} & 1.54 \mathrm{e} & 2.52 \mathrm{e}\end{array}$

${ }^{2}$ For each cultivar, treatments within columns with the same letter are not significantly different (Duncan's multiple range test, $P<0.01$ ).

\section{Discussion}

Increasing evidence from this work and elsewhere (Agusti et al., 2001; Alferez and Burns, 2004; Alferez et al., 2003) indicates that an alteration of water status in peel of several cultivars of citrus fruit triggered by exposure to low $\mathrm{RH}$ followed by high $\mathrm{RH}$ storage can promote peel pitting. In order to minimize pitting, we sought to define low RH storage time threshold values below which peel pitting does not develop after storage at high RH. 'Fallglo' tangerine is hypersensitive to postharvest peel pitting (Petracek et al., 1998). 'Fallglo' harvest season is typically short (October-November), and marked differences in RH between night and day are observed in Florida at this time. Peel pitting in 'Fallglo' tangerines was more severe than that reported in 'Marsh' grapefruit subjected to treatments designed to induce the disorder (Alferez and Burns, 2004; Table 2). Further, the low RH storage time necessary to advance peel pitting in 'Fallglo' was only 2 $\mathrm{h}$, indicating the importance of proper postharvest handling of susceptible cultivars to avoid large fluctuations in RH. Waxing did not promote peel pitting in fruit unless previous dehydration occurred. In this case, waxing substantially exacerbated peel pitting. This confirms previous results in 'Marsh' grapefruit show-
3

$0.1 \mathrm{a}$

$0.1 \mathrm{a}$

$0.31 \mathrm{~b}$

$0.34 \mathrm{~b}$

$0.50 \mathrm{c}$

$0.74 \mathrm{~d}$

0.79 de

0.93 ef

$1.15 \mathrm{f}$

$1.20 \mathrm{f}$

ing that waxing itself is not required to promote pitting, and suggests that changes in internal fruit oxygen and carbon dioxide status promoted by waxing are not key initiation factors (Alferez and Burns, 2004).

Both 'Fallglo' tangerines and 'Marsh' grapefruit showed a significant positive correlation $(P<0.01)$ between PPI at the end of high RH storage and percentage cumulative weight loss at the end of low RH storage. A high correlation coefficient was found for both cultivars when fruit were stored at low RH for periods up to $72 \mathrm{~h}$ prior to rehydration. This suggests that peel water status can be a major determinant of peel pitting when postharvest handling of the fruit is delayed during the first $3 \mathrm{~d}$ after harvest and $\mathrm{RH}$ is low. Interestingly, linear correlation was lost in 'Marsh' grapefruit when exposed for more than $72 \mathrm{~h}$ at low $\mathrm{RH}$ before rehydration, suggesting that other factors may be involved in the progression of peel pitting when low RH storage is extended in this cultivar. One explanation for this effect may be that at short durations of low RH storage, dehydrated flavedo can draw water from albedo cells, which then become water demanding. When fruit are transferred to high RH, VPD is reduced suddenly and water potential recovers faster in the outer fruit layer (flavedo) than in subtending albedo cells (Alferez et al., 2003). The increased water demand of albedo and resulting suction force may subsequently cause collapse of internal flavedo and external albedo cell layers because of their reduced ability to rehydrate (Alferez and Burns, 2004; Alferez et al., 2003). Oil glands in affected areas can become compressed and rupture, causing browning of tissue in advanced stages. If dehydration progresses for more prolonged periods of time, albedo cell layers may collapse and lose their cellular contents before rehydration treatments commence (L. Zacarias et al., unpublished data). Under these conditions, transfer to high RH may not promote a proportional increase in peel pitting, although water loss from spilled cellular contents proceeds unimpeded.

RH in the field at the time of harvest affected the development of peel pitting, as suggested for other cultivars grown under different climatic conditions (Alferezet al., 2003; Casas and Garcia-Bataller, 1986). 'Fallglo' pitted when harvested under low RH conditions and underwent a period of low $\mathrm{RH}$ postharvest storage followed by high RH storage, but pitting was much less when fruit were harvested when RH was high. Similar trends were obtained with 'Marsh' grapefruit. Under these conditions, fruit delivered to the packinghouse quickly after harvesting may not undergo sufficient evapotranspirational water loss to induce a water pressure deficit in flavedo and albedo tissues capable of inducing peel pitting after transfer to $90 \% \mathrm{RH}$. Unfortunately, harvest at high $\mathrm{RH}$ also 

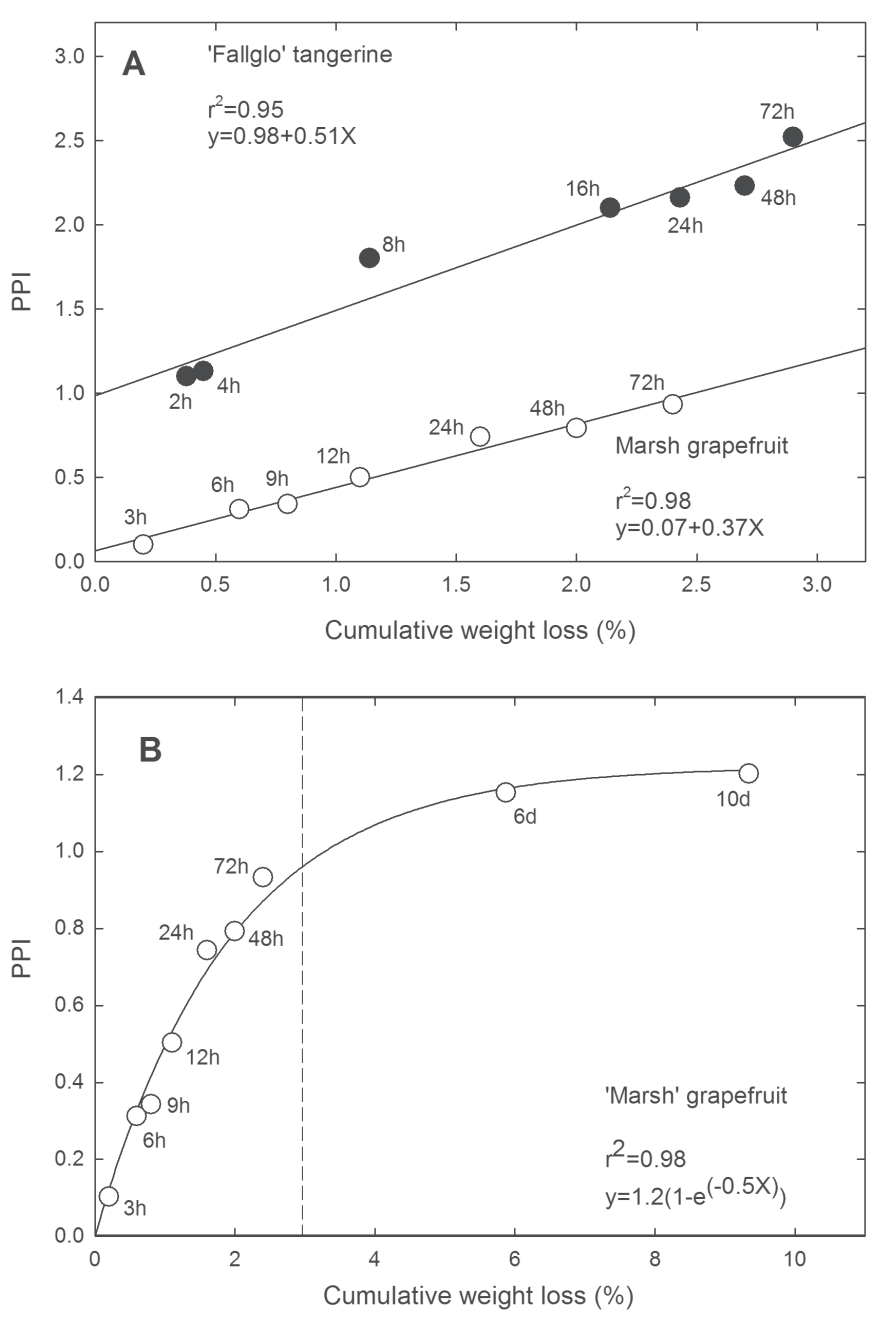

Fig. 3. Correlation plots between cumulative weight loss percentage at the end of $30 \%$ relative humidity $(\mathrm{RH})$ storage and peel pitting index (PPI) at the end of 90\% RH storage. (A) 'Marsh' grapefruit (O) stored for 3, 6, 9, 12, 24, 48, and $72 \mathrm{~h}$ at $30 \% \mathrm{RH}$ and 'Fallglo' tangerine (@) stored for 2, 4, 8, 16, 24, 48, and $72 \mathrm{~h}$ at $30 \% \mathrm{RH}$ prior to washing, waxing and storage at $90 \%$ RH. (B) 'Marsh' grapefruit stored for $3 \mathrm{~h}, 6 \mathrm{~h}, 9 \mathrm{~h}, 12 \mathrm{~h}, 24 \mathrm{~h}, 48 \mathrm{~h}, 72 \mathrm{~h}, 6 \mathrm{~d}$, and $10 \mathrm{~d}$ at $30 \%$ prior to wash, wax, and storage at $90 \% \mathrm{RH}$. Temperature of storage was $20^{\circ} \mathrm{C}$. Dashed vertical line depicts the relative break from the linear relationship.

increases susceptibility of fruit to oleocellosis when harvested by hand (Grierson, 1986). However, the impact of oleocellosis could be reduced or eliminated by clipping fruit at the pedicel. These observations agree with previous work that showed that fruit from groves subjected to severe drought stress conditions had less capability of water potential adjustment and developed greater peel pitting, whereas fruit harvested from groves under less extreme dehydration conditions were able to fully recover water potential, and peel pitting was reduced (Alferez et al., 2003). Further, flavedo of fruit harvested from defoliated branches of 'Navelate' sweet oranges had higher water potential and developed less peel pitting than fruit from nondefoliated branches in which water potential of flavedo was more negative (Agusti et al., 2003). In the current study, one plausible explanation for the increased susceptibility of fruit to peel pitting when harvested at low RH is that water movement within harvested fruit may be restricted by severing vascular connections from the water source in the parent tree. As a result, water potential may become more
A
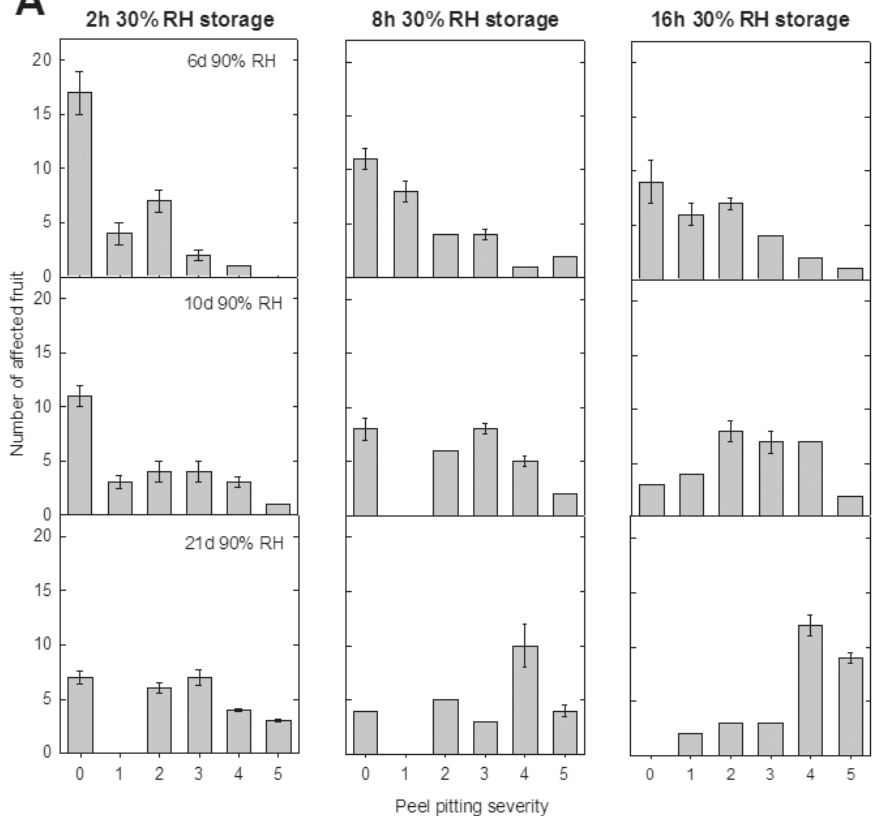

B
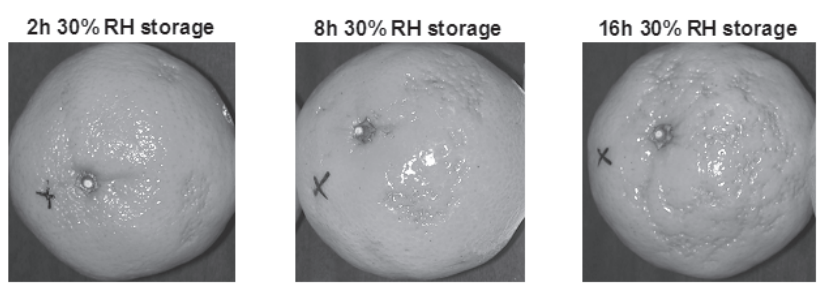

Fig. 4. Peel pitting severity and number of fruit affected in 'Fallglo' tangerine. (A) Fruit were stored at 2,8 , or $16 \mathrm{~h}$ at $30 \%$ relative humidity $(\mathrm{RH})$ prior to washing, waxing and storage at $90 \% \mathrm{RH}$ for $21 \mathrm{~d}$. Peel pitting severity was rated using a visual scale based on the number of collapsed oil glands/fruit $(0=$ no pits, $1=$ 1 to 3 pits, $2=4$ to 10 pits, $3=11$ to 30 pits, $4=31$ to 100 pits, $5=$ more than 100 pits). (B) Images depict the typical appearance of fruit at the end of a $21-d$ storage period at $90 \% \mathrm{RH}$. Temperature of storage was $20^{\circ} \mathrm{C}$.

negative, increasing the potential for peel pitting. Water movement in fruit harvested at high RH would be less restricted and water potential may remain higher.

In conclusion, we have shown that 'Fallglo' tangerines can develop peel pitting by changing storage relative humidity from low to high. Comparison of this cultivar with 'Marsh' grapefruit has shown that RH at the time of harvest has an effect on the susceptibility of fruit to peel pitting, and that in general, the development of peel pitting in 'Marsh' is less severe than 'Fallglo'. In susceptible cultivars such as 'Fallglo', harvesting at low RH should be avoided and the elapsed time between harvesting, postharvest handling and storage in the packinghouse should be minimized.

\section{Literature Cited}

Agusti, M., V. Almela, M. Juan, F. Alferez, F.R. Tadeo, and L. Zacarias. 2001. Histological and physiological characterization of rind breakdown of Navelate sweet orange. Ann. Bot. 88:422-451.

Agusti, M., V. Almela, M. Juan, C. Mesejo, and A. Martinez-Fuentes. 2003. Rootstock influence on the incidence of rind breakdown in 
Table 3. Field relative humidity (RH) at harvest affects development of peel pitting. 'Fallglo' tangerines and 'Marsh' grapefruit were harvested at disparate RH conditions, then stored for $3 \mathrm{~d}$ ('Fallglo') or $6 \mathrm{~d}$ ('Marsh') at $30 \% \mathrm{RH}$ and then washed, waxed, and transferred to $90 \% \mathrm{RH}$ for $21 \mathrm{~d}$. Temperature of storage was $20^{\circ} \mathrm{C}$.

\begin{tabular}{|c|c|c|c|}
\hline & RH field conditions & $\begin{array}{l}\text { Days at } \\
30 \% \mathrm{RH}\end{array}$ & $\begin{array}{l}\text { PPI after } \\
\text { at }\end{array}$ \\
\hline Date of Harvest & At harvest Previous $2 \mathrm{~d}$ & after harvest & $90 \% \mathrm{RH}$ \\
\hline
\end{tabular}

Date 1

28 Oct. 2003

$89 \%\left(330 \mathrm{~Pa}^{\mathrm{z}}\right) \quad 70-96 \%$

0

0

1

3

0

0

Date 2

13 Nov. 2003

$\begin{array}{llll}42 \%(1950 \mathrm{~Pa}) \quad 46-97 \% & 0 & 0.15^{\mathrm{y}} \pm 0.02 \\ & 1 & 2.16 \pm 0.20 \\ & 3 & 2.52 \pm 0.30\end{array}$

‘Marsh' grapefruit

Date 1

11 Mar. 2004

$\begin{array}{ccc}39 \%(1520 \mathrm{~Pa}) \quad 30-92 \% & 0 & 0 \\ & 1 & 0.50 \pm 0.03 \\ 3 & 0.55 \pm 0.04 \\ 6 & 0.67 \pm 0.02\end{array}$

Date 2
16 Mar. 2004

\begin{tabular}{|c|c|c|c|c|}
\hline \multirow[t]{4}{*}{16 Mar. 2004} & $94 \%(150 \mathrm{~Pa})$ & $66-95 \%$ & 0 & 0 \\
\hline & & & 1 & 0 \\
\hline & & & 3 & 0 \\
\hline & & & 6 & 0 \\
\hline
\end{tabular}

${ }^{2}$ Numbers in parenthesis are vapor pressure deficit. yPeel pitting indices (PPI) are shown as means \pm SE.

(PPI) are shown as means \pm se.
'Navelate' sweet orange. J. Hort. Sci. Biotech. 78:537-548.

Alferez, F., M. Agusti, and L. Zacarias. 2003. Postharvest rind staining in Navel oranges is aggravated by changes in storage relative humidity: effect on respiration, ethylene production and water potential. Postharvest Biol. Technol. 28:143-152.

Alferez, F. and J. Burns. 2004. Postharvest peel pitting at non-chilling temperatures in grapefruit is promoted by changes from low to high relative humidity during storage. Postharvest Biol. Technol. 32:79-87.

Casas, A. and L. Garcia-Bataller. 1986. Manchas en las naranjas Navelina. Revista de Agroquimica y Tecnologia de Alimentos. 26:309-317.

Grierson, W. 1986. Physiological disorders, pp. 25-43. In: W.F. Wardowsky, S. Nagy, and W. Grierson (eds.). Fresh citrus fruits. AVI, Westport, Conn.

Lafuente, M.T. and J.M. Sala. 2002. Abscisic acid and the influence of ethylene, humidity and temperature on the incidence of postharvest rindstaining of Navelina oranges (Citrus sinensis L. Osbeck) fruits. Postharvest Biol. Technol. 25:49-57.

Petracek, P.D., L. Montalvo, H. Dou, and C. Davis. 1998. Postharvest pitting of 'Fallglo' tangerine. J. Amer. Soc. Hort. Sci. 123:130 135.

Petracek, P.D., W.F. Wardowski, and G.E. Brown. 1995. Pitting of grapefruit that resembles chilling injury. HortScience 30:1422-1426. 